\title{
Beliefs about Language Learning in Study Abroad: Advocating for a Language Ideology Approach
}

\section{Victoria Surtees \\ University of British Columbia}

For the last two decades, study abroad (SA) scholars have worked tirelessly to dismantle the popular belief that SA is a magic bullet for language learning (Allen \& Dupuy, 2012; DeKeyser, 2010; Diao, Freed, \& Smith, 2011; Kinginger, 2009; Pellegrino, 1998; Wilkinson, 1998). In her landmark paper published almost two decades ago, Freed (1998) shed light on the power of this "myth", pointing out how SA is frequently conceptualized as a full immersion experience where students will not have to put forth effort, but will learn naturally simply by being surrounded by the language. She encouraged scholars and program designers to reflect critically on students' beliefs about homestay or access to cooperative native speakers. Her hope was that empirical evidence from studies investigating language gains in SA would make "us consciously aware of some of the myths associated with the study abroad experience and sensitize us to the weakness of some of these longheld assumptions about the study abroad experience" (Freed, 1998, p.52). Twenty years later, however, the same beliefs are recurring in students' descriptions of why they wish to undertake SA (Allen \& Dupuy, 2012; Zemach-Bersin, 2009). In addition, a growing body of research is showing these pre-sojourn expectations play a significant role in how students actually perceive their language learning experiences (Allen, 2010; Doerr, 2015; Hernández, 2010; Isabelli-Garcia, 2004; Lee, 2014; Li, Olson, \& Hanson Frieze, 2012; Pyper \& Slagter, 2015; Trenchs-Parera \& Juan-Garau, 2014). So where do these beliefs come from and why do they persist in spite of ample evidence to disprove them? I propose that it is not productive to treat students' expectations as the beliefs of those who have not yet been "made aware" of the realities of language learning in SA. Instead, I advance that a language ideological framework may allow us to reconceptualise these beliefs as socially and historically constituted language ideologies, and thereby move beyond the individual to examine programmatic, institutional and interactional roles in the reproduction of these beliefs.

Language ideologies are shared beliefs about language or language use which are mobilized as meaning making resources in interaction and are themselves reproduced and transformed through such use (Woolard \& Schieffelin, 1994). With the social and critical turns in education and applied linguistics, there has been increased focus on the role of language ideologies, discourses and narratives as a way to connect macro and micro phenomena, such as language policy and everyday language practices, and to critically interrogate the fields' longstanding assumptions about the nature of language(s) (see De Costa, 2011 for a review of ideology approaches to second language acquisition). SA research, however, has typically preferred approaches to beliefs that rely on psychosocial frameworks, which view actions and experiences as the result of individuals' actions, knowledge, and desires. In this paper, I review the insights gained from beliefs research in SA and 
consider how a language ideological framework might further our understanding of why these beliefs appear at times contradictory and how they continue to be reproduced. Such an approach complements the steadily emerging body of work that has examined the role of discourses and assumptions related to SA and how they shape the student experience (Caton \& Santos, 2009; Diao et al., 2011; Doerr, 2012, 2015; Gore, 2005; Härkönen \& Dervin, 2015; Iino, 2006; Kinginger, 2008; Siegal, 1996; Zemach-Bersin, 2009).

\section{Beliefs about language learning in Study Abroad}

SA studies have investigated a wide range of beliefs-related topics that revolve around language. These topics are referred to using a variety of terms, including attitudes towards the target language (e.g., French as a romantic language, or Japanese as a difficult language to learn), beliefs about homestay (e.g., homestay parents will be caring), motivations for undertaking SA, and changes in perceptions about the self as a language learner (e.g., increased confidence or perceived language ability). Research investigating beliefs has most often conceptualized SA assumptions through the lens of social psychology. In this approach, beliefs are viewed as subjective internal mental representations that can be contrasted with the more objective construct "knowledge" (Verschueren, 2012). In other words, what students say (their beliefs) is contrasted with "reality" (first-hand experience or measured outcomes) with the expectation that the two are often divergent. For example, an SA student might believe they will make many native speaker friends, and find from experience that this is more difficult than excepted.

De Costa (2011) distinguishes broadly between three types of psycho-social belief research: normative, meta-cognitive, and contextual. According to him, the normative and metacognitive traditions view beliefs as stable variables, while the contextual approach acknowledges that learners' beliefs are shaped by their experiences, and are thus dynamic and responsive to context. In the SA literature, studies adopting normative and metacognitive approaches investigate students' intentions as well as motivations for studying abroad and their beliefs about SA benefits and barriers to participation (Brux \& Fry, 2010; Gore, 2005; Nguyen, 2014; Park, 2012; Sivakumaran, Tomida, Hall, \& Sumida, 2013; Stroud, 2010; Wanger, Minthorn, Appleman, James, \& Arnold, 2012; Zhang \& Sun, 2014). These studies, which use focus groups or one-shot questionnaires with large samples, correlate findings with demographic data such as socio-economic status, major, and ethnicity. In this sense, they seek to establish connections between particular types of beliefs and social groups. Unsurprisingly, findings confirm that for programs involving a language component, most students, regardless of social category, perceive foreign language learning as an important benefit of SA. ${ }^{1}$ While normative studies provide important insights, particularly on what students perceive as barriers to participation, the majority of belief studies about language learning in SA adopt a contextual approach which recognizes that belief systems can be shaped by experience. These studies have tracked changes in beliefs over time by comparing pre-/post or cross-sectional questionnaire and/or interview data (e.g., Tanaka \& Ellis, 2003; Trenchs-Parera \& Juan-Garau, 2014) or by qualitatively analyzing narratives in journal entries (e.g., Wilkinson, 1998; Yang \& Kim, 2011). ${ }^{2}$

${ }^{1}$ Although a survey of American college-bound students indicated that only $9 \%$ chose language learning as their top reason for studying abroad, while $73 \%$ chose travel or expanding cultural horizons as their prime reasons (American Council on Education, 2008).

${ }^{2}$ De Costa (2011) places questionnaire research in the normative category, owing to the fact that etic categories are 
Findings across this research revolve around two main themes. In the first theme, the SA experience is positioned as impacting learners' beliefs in their own language learning abilities by helping them feel more or less confident, autonomous and strategic. Studies belonging to the second theme, on the other hand, qualitatively document how unrealistic expectations tend to leave students with a sense of "missed opportunities" (Mendelson, 2002, p.49). They also showcase exceptional students who, when faced with realities that conflict with their assumptions and goals, are able to reorient their belief systems and formulate new and more effective language learning strategies. Table 1 lists a selection of quantitative and qualitative research for which beliefs were a main focus and indicates the types of beliefs investigated. ${ }^{3}$

Table 1. Selected language-related beliefs research in study abroad

\begin{tabular}{|c|c|c|c|c|}
\hline Approach & Study & $\begin{array}{l}\text { Participants/L2/ } \\
\text { context }\end{array}$ & Constructs & Topics \\
\hline $\begin{array}{l}\text { - Quantitative contextual } \\
\text { • Questionnaires }\end{array}$ & $\begin{array}{l}\text { *Amuzie \& Winke } \\
\text { (2009) }\end{array}$ & $\begin{array}{l}70 \text { various ( } 2 \\
\text { focal), English, } \\
\text { USA }\end{array}$ & Belief & $\begin{array}{l}\text { Ratings of importance of } \\
\text { teacher's role, autonomy, self- } \\
\text { efficacy }\end{array}$ \\
\hline \multirow{5}{*}{$\begin{array}{l}\text { - Imposed etic categories } \\
\text { - Examines pre-post } \\
\text { differences }\end{array}$} & $\begin{array}{l}\text { Izumi, Shiwaku, } \\
\text { Okuda (2011) }\end{array}$ & $\begin{array}{l}182 \text { Japanese, } \\
\text { English, various }\end{array}$ & Beliefs & $\begin{array}{l}\text { Ratings of confidence, } \\
\text { importance of analytic and } \\
\text { experiential learning }\end{array}$ \\
\hline & $\begin{array}{l}\text { *Kaypak \& } \\
\text { Ortaçtepe (2014) }\end{array}$ & $\begin{array}{l}53 \text { Turkish, } \\
\text { English, Europe }\end{array}$ & Beliefs & $\begin{array}{l}\text { Ratings of self-efficacy and } \\
\text { autonomy, importance of } \\
\text { learning English }\end{array}$ \\
\hline & $\begin{array}{l}\text { *Pyper \& Slagter } \\
(2015)\end{array}$ & $\begin{array}{l}135 \text { American, } \\
\text { Spanish, various }\end{array}$ & Perceptions & $\begin{array}{l}\text { Ratings of proficiency and } \\
\text { expected improvement, } \\
\text { barriers and hindrances to } \\
\text { acquisition }\end{array}$ \\
\hline & $\begin{array}{l}\text { Tanaka \& Ellis } \\
(2003)\end{array}$ & $\begin{array}{l}166 \text { Japanese, } \\
\text { English, USA }\end{array}$ & $\begin{array}{l}\text { Motivations/ } \\
\text { beliefs }\end{array}$ & $\begin{array}{l}\text { Ratings of self as learner, } \\
\text { importance of analytic and } \\
\text { experiential learning }\end{array}$ \\
\hline & $\begin{array}{l}\text { Trenchs-Parera \& } \\
\text { Juan-Garau (2014) }\end{array}$ & $\begin{array}{l}70 \text { Spanish, } \\
\text { English, various }\end{array}$ & Beliefs & $\begin{array}{l}\text { Ratings of motivation, attitude } \\
\text { toward English, anxiety, } \\
\text { willingness to communicate, } \\
\text { importance of language skills }\end{array}$ \\
\hline
\end{tabular}

used to generate questionnaire items. However, in my view, any research which assumes experience can have a significant impact on beliefs is more appropriately categorized as contextual.

3 Other qualitative studies have discussed mismatches between participants' expectations and realities as part of a broader study, often in relation to identity (e.g., Benson, Barkhuizen, Bodycott, \& Brown, 2012; Jackson, 2008; Kinginger, 2008; Pellegrino, 2005). 
Table 1 (continued). Selected language-related beliefs research in study abroad

\begin{tabular}{|c|c|c|c|c|}
\hline Approach & Study & $\begin{array}{l}\text { Participants/L2/ } \\
\text { context }\end{array}$ & Constructs & Topics \\
\hline - Qualitative contextual & Allen (2010) & $\begin{array}{l}6 \text { US, French, } \\
\text { France }\end{array}$ & $\begin{array}{l}\text { Motives/ } \\
\text { goals/ beliefs }\end{array}$ & $\begin{array}{l}\text { Beliefs about SA linguistic } \\
\text { benefits, linguistic goals }\end{array}$ \\
\hline \multicolumn{5}{|l|}{$\begin{array}{l}\text { • Interviews, journals, } \\
\text { ethnography }\end{array}$} \\
\hline $\begin{array}{l}\text { - Elicited explicit and } \\
\text { inferred categories } \\
\text { - Examines differences }\end{array}$ & *Mendelson (2002) & $\begin{array}{l}43 \text { US ( } 4 \text { focal), } \\
\text { French, France }\end{array}$ & Expectations & $\begin{array}{l}\text { Goals and expectations for } \\
\text { informal vs. classroom } \\
\text { contact, role of native } \\
\text { speakers, self-rated } \\
\text { proficiency }\end{array}$ \\
\hline \multirow{3}{*}{$\begin{array}{l}\text { - Examines differences } \\
\text { between experiences and } \\
\text { expectations and resulting } \\
\text { changes }\end{array}$} & $\begin{array}{l}\text { Miller \& Ginsberg } \\
\text { (1995) }\end{array}$ & $\begin{array}{l}80 \text { US, Russian, } \\
\text { Russia }\end{array}$ & $\begin{array}{l}\text { Folklinguistic } \\
\text { theories }\end{array}$ & $\begin{array}{l}\text { Theories of language and } \\
\text { learning strategies }\end{array}$ \\
\hline & Wilkinson (1998) & $\begin{array}{l}2 \text { Korean, English, } \\
\text { USA/Philippines }\end{array}$ & Expectations & $\begin{array}{l}\text { Beliefs about immersion in } \\
\text { homestay }\end{array}$ \\
\hline & $\begin{array}{l}\text { Yang \& Kim } \\
(2011)\end{array}$ & $\begin{array}{l}2 \text { US, French, } \\
\text { France }\end{array}$ & $\begin{array}{l}\text { Beliefs/ } \\
\text { motivations }\end{array}$ & $\begin{array}{l}\text { Beliefs about the role of social } \\
\text { interaction and native speakers }\end{array}$ \\
\hline
\end{tabular}

*Studies that incorporated mixed methods (e.g., questionnaires supplemented with interview data)

\section{Learner and language-centred beliefs: self-efficacy, autonomy, and learning styles}

Scholars in applied linguistics have long posited a relationship between the use of language in authentic contexts and the strengthening of students' beliefs in their self-efficacy, autonomy, and motivation as additional language speakers (Gilmore, 2007). Contrary to expectations, however, findings from the studies reviewed here show that contact with native speakers, sometimes resulted in decreased confidence in language abilities.

Amuzie and Winke (2009) investigated beliefs of 70 students, mainly from China and Korea, enrolled in general or ESL programs with other local native speakers in the USA and found that students rated their pre-sojourn self-efficacy as significantly higher than their mid-sojourn efficacy, indicating a marked decrease in confidence. Similarly, Kaypak and Ortaçtepe (2014) found that 53 Turkish Erasmus students studying in English-medium programs across Europe reported no significant changes in beliefs overall apart from being more afraid of making mistakes after a fivemonth sojourn. Using data from focal participants' journals entries, they discovered that most students expressed a decrease in fear when speaking with other second language speakers, but no change or in some cases increased apprehension in communicating with native speakers. Interestingly, though both studies found decreases in self-efficacy, they also found increases in learners' self-rated autonomy, indicating that although learners felt less confident about their abilities as users, they felt more confident in their ability to learn independently following an SA experience.

Providing a more dynamic portrait of participants' perceived self-efficacy, Mendelson (2002) found that $75 \%$ of her US participants, who were enrolled in a 14 week program in Spanishspeaking Granada, described decreased confidence in their language abilities after their third week of 
study; however, by the end of the sojourn most students were "fairly positive about their progress" (p.48). ${ }^{4}$ Tanaka and Ellis (2003) and Pyper and Slagter (2015) also found positive outcomes, reporting significant increases in self-efficacy ratings for 166 Japanese participants and 135 American students respectively. However, while the students in Pyper and Slagter's research lived in homestays and reported interacting in their target language, Spanish, approximately $75 \%$ of the time, Tanaka and Ellis are quick to point out that their program resembled a "Japanese College overseas" (2003, p.81) more than a traditional SA experience and that students had little contact with US native speakers.

These questionnaire-based studies have also explored changes in students' beliefs about how a language is best learned and which facets of the language are the most important. Ellis and Tanaka (2003) measured students' pre-/post sojourn beliefs about the importance of experiential and analytic learning, finding that beliefs about the importance of both were strengthened with a higher increase for beliefs about experiential learning. Similarly, Izumi et al. (2011) compared beliefs about experiential and analytical learning for 104 students with SA experience to those of 74 students with no SA experience. They also found that SA students had stronger beliefs in the importance of experiential learning as a result of time spent learning English abroad. Mendelson (2002), on the other hand, found that while students initially prioritized informal out of class contact almost exclusively, the difficulties they experienced trying to connect with locals abroad lead them to report placing increased value on formal classroom contact. It is interesting to note that in these studies, the students beliefs tended toward the priorities of the educational systems where they sojourned: in the first two studies, students from Japan sojourned in the USA where experiential learning is often prioritized, while for Mendelson's study, it was American students who were attending courses in Spain, where more analytic methods were prioritized. This certainly hints at the role that broader institutional practices may have in shaping the beliefs of students.

The results of these studies show that while SA certainly appears to interact with learners' beliefs about themselves as language users and about language learning in significant ways, the outcomes are variable and sometimes quite contrary to what the authors themselves predict (see especially Kaypak \& Ortaçtepe, 2014). While according to the SA myth, native speaker contact is highly valuable, in these studies, it sometimes resulted in decreased language confidence. Mendelson (2002) posits that this may have been a result of students' overvaluation of their own proficiency pre-sojourn. He found that students self-rated their proficiency a full level higher than their corresponding test results on the Oral Proficiency Index (OPI). Pyper and Slagter (2015) noted a similar tendency of students to over rate their pre-sojourn proficiency. Tanaka and Ellis (2003) also found no correlations between students' self-ratings and their performance as measured by the TOEFL. It would appear that changes in participants' beliefs about their language ability are less a reflection of gains than the product of their experiences and expectations before and during their sojourns. These experiences have been more closely examined by qualitative research in this area.

4 This appears to be a sheltered program similar to Tanaka and Ellis (2003) but with a homestay option although it is unclear from the article. 


\section{Context-centred beliefs: Idealistic expectations about the SA environment}

Qualitative studies have highlighted the role that pre-sojourn expectations can play in students' reported satisfaction with their learning outcomes. Findings show, through the thick description of individual trajectories, that often the "myths" of SA do not reflect students' lived experiences. When one or more of these beliefs do not match reality, SA students face the challenge of adapting their expectations, which they do with varying degrees of success. Those who reconceptualise their experiences report high degrees of satisfaction; those who do not tend to report disappointment (Allen, 2010).

Yang and Kim (2011) investigated "the hidden logic of each learner's idiosyncratic L2 belief changes" (p.326) by describing the contrasting trajectories of two Korean SA students: Yong, who did his SA sojourn in Utah and believed that interaction with native speakers was the key to fluency; and Hye-In, who studied in the Philippines and believed that personalized teacher feedback, especially on her writing, was the key to development. During the sojourn, Yong experienced disillusionment when his English-speaking roommate was apathetic toward his linguistic development and shifted his belief that native speaker contact was the best way to learn a language. Hye-In, on the other hand, found social interaction with private tutors highly beneficial and in turn reoriented her beliefs to prioritize social encounters as tools for language development. Thus, while Hye-In was able to be flexible and create a positive SA experience for herself, Yong is described as becoming "aloof" (p.329) and being disappointed with his sojourn. The authors cite Yong's beliefs as a major contributor to his disappointment: "[w] hen he began to doubt the effectiveness of SA participation in developing L2 communication skills, the L2 learning environment did not play a facilitative role in developing his L2 fluency skills (p.332)." From these findings, they conclude that students must set language learning goals that are compatible with what is achievable in their context.

Likewise Wilkinson (1998), in her paper on two US sojourners' experiences in French homestays, documents how participants initially expected to be treated like members of the family and how this impacted outcomes. The first sojourner, Molise, had her expectations confirmed and thus did not need to adjust: her family took her to the countryside, welcomed her warmly, and was supportive and patient with her language development. The second sojourner, Ashley, was disappointed with her host family, who she viewed as impatient and inattentive with her attempts to speak French. Thus, Wilkinson claims that students' initial perspectives on the homestay experience interacted with their lived realities to produce satisfaction in the case of Molise and dissatisfaction for Ashley. Unlike Yang and Kim (2011), however, Wilkinson cautions against adopting a singular explanation for their reactions, saying "other factors, such as their level of language proficiency, the nature of the pre-departure preparation meetings, the absence of an on-site director, their own cross-cultural experiences prior to their stay in France, and so forth, all had an impact as well (1998, p. 133)."

Unlike the previous studies, Miller and Ginsberg (1995) focused on folklinguistic theories. The notion of folklinguistic theories acknowledges that beliefs about language that are observable through behavior and talk "mirror broader cultural conceptions, academic approaches to second language learning, and assumptions" (Miller \& Ginsberg, 1995, p.312). Applying this concept to the 
SA context, Miller and Ginsberg examined the language learning journals of 80 US students in Russia and inferred the unstated implicit assumptions about the nature of language and language learning embedded within the narratives. The authors found many parallels between students' folklinguistic theories and cognitive and universal grammar approaches dominant in the 1970s and 1980s. Students viewed language as a system of fixed grammatical rules in which words had transparent denotational meanings and the mind was conceptualized as having separate language containers in which new words and grammar structures were placed. Miller and Ginsberg also found that native speakers were not seen as potential friends but more often viewed as "guinea pigs" on which to test new words and structures (p.307). Miller and Ginsberg's study has the advantage of formally acknowledging the parallels between students' beliefs and the more widely circulating beliefs in language learning literature and society. Thus rather than pointing out the erroneous nature of students folk theories Miller and Ginsberg put forward that they are "obviously not arbitrary individual constructions" (p.312) and propose that "changes must be made in all phases of the curriculum [...] in the way languages as systems are presented and in the way learning is structured" (p.313). Thus, their approach differs substantially from that adopted by the other authors here, such as Yang and Kim (2011), who present learner-centred implications that encourage more specific goal setting rather than critically interrogating the origins of beliefs.

\section{Identifying the gaps}

Contextual studies admit the dynamic and sometimes contradictory nature of students' perspectives and are thus a first step to recognizing how beliefs serve as interpretative resources for making sense of language learning during an SA experience. However, across these studies, beliefs are still largely framed as learner-internal rather than socially or discursively constructed. The external environment is seen to provide new data that challenge students' beliefs and which students draw on to transform their beliefs and their basis for social action (Allen, 2010; Yang \& Kim, 2011). In other words, beliefs are presented as stable across contexts until a triggering event causes a reevaluation. In questionnaire-based research, this triggering event is operationalized as the entire SA experience, as if SA were a controlled pedagogical treatment. Qualitative studies provide more complex portraits of triggering events ranging from the general lived realities of individual students to descriptions of a few critical incidents with locals or homestay families.

By presenting beliefs as mainly internal, students can be implicitly framed as responsible for their beliefs and thus equally responsible if their beliefs are not conducive to the desired outcomes of SA. This can lead to conclusions that blame students for their lack of awareness about their SA experience or alternatively their lack of flexibility or willingness to change their beliefs when confronted with adversity (see especially Yang \& Kim, 2011). Pyper and Slagter (2015), for instance, conclude from their study of 135 American students' perceptions of the hindrances and aids to acquisition that "one of the primary underlying factors behind successful language study in SA contexts is the intentionality of the participants" engagement with the various elements of the SA program (p.97)." Indeed, Allen and Dupuy (2012) acknowledge that it may be "tempting" to conclude that the negative outcomes found in the research are "due to students' lack of motivation to integrate into communities abroad" (p.478). Pelligrino (1998) terms this the "lazy student myth" (p.97) in which students who do not display exceptional resourcefulness and effort are dismissed as lost causes. If SA research is to have implications that extend beyond individual students' motivation or effort, it seems reasonable to also investigate how institutions and other stakeholders co- 
construct these expectations which are so central to participants' subjective impressions of their experience. Secondly, these studies do not account for the historical constitution of students' beliefs. In other words, they do not address the issue of how students came to have these expectations in the first place. While a few studies mention the influences of styles of instruction or experiences using the language (Kaypak \& Ortaçtepe, 2014; Wilkinson, 1998; Yang \& Kim, 2011), of the studies reviewed here, only Miller and Ginsberg (1995) analyzed wider circulating discourses about language as central to the research.

Meanwhile, SA research on policy and advertising is showing clear parallels between students' and teachers' SA expectations and locally circulating institutional messages. Allen and Dupuy (2012) discuss how the "Communities Standard" for foreign language education in the USA is reflected in student and teacher attitudes toward SA. This national policy specifies learning outcomes for language education and is a guiding document for program design which references the importance of "Traveling to communities and countries where the language is used extensively to further develop their language skills and understanding of the culture" (National Standards, 2006 as cited in Allen \& Dupuy, 2012, p.469). The authors proceed to review a large number of studies which compare students SA priorities and those set forth in the Communities Standard finding that "U.S. college students' own views of the value of study abroad reflect the merit assigned to such experiences by their educational institutions" (p.470). The views of experienced teachers and administrators, however, often diverge and "many perceive that attaining this goal is beyond students' capabilities given limited resources and relatively short sequences of study" (p.470). Allen and Dupuy conclude that "it is important to consider how students come to internalize their roles as [foreign language] users during classroom study and the consequences of holding onto those roles once abroad (2012, p.478).”

Zemach-Bersin (2009) also compared the underlying narratives of SA advertising and the presojourn expectations of 22 students at a liberal arts college in the USA. She found that advertisements depicted SA as an exotic adventure and commodity designed "primarily for the individual consumer's self-improvement and personal fulfillment" (p.306). The student narratives elicited in interviews mirrored those found in the SA advertisements, and many students described SA as an expected rite of passage, a break from everyday campus life, and a guaranteed life-changing experience that would require little preparation or effort. Indeed a number of researchers have pointed to the connection between students' conception of study abroad as adventure and traditional notions of the "grand tour" (e.g., Doerr, 2012; Gore, 2005; Kinginger, 2008).

These gaps indicate that perhaps an alternate frame is necessary to explain some of the contradictions found in beliefs research and to more systematically account for the role of students' beliefs in shaping their experiences. Indeed, a number of qualitative studies have drawn on the notions of norms, discourses, folk beliefs, or narratives to point to the broader social antecedents of students beliefs and assumptions (Diao, 2014; Doerr, 2015; Iino, 2006; Siegal, 1996). Cook (2006), for instance, examined how folk beliefs about language learning and culture were discussed by eight American SA students and their Japanese host families during meal times. Drawing on recorded conversations rather than reflections or interviews, Cook drew parallels between how the families and students discussed Japanese food, culture, and language and the ideology of nihonjinron which "states that the Japanese are unique and different from the rest of the world" (p.123). This ideology 
assumes that the uniqueness of Japanese culture makes it especially challenging for foreigners and according to Cook, appeared to frame many of their conversations (e.g., host parents were surprised and impressed that students liked Japanese food). She found that through mealtime discussions, the SA students learned to participate in conversations framed by notions of nibonjinron by recognizing and acknowledging the uniqueness of Japanese culture and in some cases to challenge and negotiate this ideology with their host families. Thus Cook views folk beliefs as co-constructed and flexible frames upon which speakers can draw to make sense of conversations. He also emphasizes how conversations about beliefs are "opportunity spaces" not only for SA students but also for the host families with whom they converse. I propose that like Cook's notion of folk beliefs, a language ideology perspective would provide a promising avenue for exploring the "myths" of SA and how they frame students' everyday encounters. In the following section, I describe the theoretical foundations of work in this area.

\section{Language ideologies}

The study of language ideologies emerged as a coherent subfield in linguistic anthropology in the 1990's with the publication of a volume edited by Woolard and Schieffelin (1998). Language ideologies and beliefs are in many ways intertwined concepts. Similar to the SA beliefs research reviewed in the first section, language ideology research addresses beliefs about language(s) and language learning (e.g., English is a world language, native speakers are the best teachers), popular notions about how certain people should speak (e.g., in the USA, people speak English), as well as how situated language use is implicated in the reproduction and transformation of such ideologies (Blommaert, 2006; Kroskrity, 2004; Woolard, 1998). ${ }^{5}$ They have been defined as "shared bodies of commonsense notions about the nature of language in the world" (Rumsey, 1990, p.346) or alternatively, as "representations, whether explicit or implicit, that construe the intersection of language and human beings in a social world" (Woolard, 1998, p.3). Thus, in contrast with psychosocial research which views beliefs as stable and internal, language ideologies are viewed as socially constructed resources shared by a community as norms or common sense. Verschueren (2012) aptly describes this distinction in his volume on investigating ideologies in research:

Ideas, beliefs and opinions in as such do not make ideology. Simplifying a bit, they are merely 'contents of thinking,' whereas ideology is associated with underlying patterns of meaning, frames of interpretation, world views, or forms of everyday thinking and explanation. Thus the ways in which beliefs, ideas or opinions are discursively used, i.e., their forms of expression as well as the rhetorical purposes they serve, are just as important for ideology as the contents of thinking for which these three terms serve as labels. (p. 7, original emphasis)

Language ideology research rests on several important assumptions about how beliefs are used and transformed in everyday communication. In the following sections, I describe each of these assumptions and provide illustrative examples.

${ }^{5}$ Some scholars prefer the general term ideology (e.g., Blommaert, 2005; Darvin \& Norton, 2015), particularly for research on the role of language use in the reproduction of ideologies and the links between ideologies and identities, noting that the lines between what can be classified as a language ideology vs. a general ideology are blurry at best. 


\section{Resources for mediating meaning-making}

Firstly, language ideologies are seen to mediate the process of meaning-making by serving as recognizable rationales, or interpretative frameworks, for the valuation of others' or one's own actions (Gal, 1998; Silverstein, 1992). In other words, language ideologies are attitudes about language which individuals or groups use to frame social actions as (il)legitimate and thus to account for responses to such actions. For example, Razfar and Rumenapp (2012) investigated ideologies related to the English-only policy in one English as-a-second-language (ESL) classroom. Englishonly policies draw on the assumption that maximum language exposure is of benefit to students. The authors show how the acceptance of this ideology is used as a resource by teachers to legitimately scold students who speak languages other than English during school activities. The students, who also recognize this ideology, accept the scolding and in most cases revert to English.

This example highlights how language ideologies can only be drawn upon to successfully legitimate actions if other parties also recognize them as valid socially circulating resources. However, it is important to note that recognition of an ideology does not necessarily entail that all parties involved believe it to be true or fair. It indicates only that the ideology can be mobilized as a legitimate rationale interpretable by others. For example, as a language educator, I may not believe that native speaker competence is the ultimate target for language acquisition; however, it remains an ideological resource that I must recognize to understand the goals and actions of many of my students.

\section{Multiple, dynamic, and contradictory in nature}

Secondly, language ideologies are understood to be multiple and dynamic in nature and can thus be drawn upon and locally produced in contradictory ways. Olivo (2003), for example, highlights how ESL teachers at a high school in Toronto produced conflicting ideologies about the role of student talk in the classroom. He found that while teachers explicitly expressed beliefs linking oral practice to language acquisition in interviews, in class the teachers' actions reflected an implicit ideology that construed talking and working/learning as fundamentally separate activities. What this demonstrates is that teachers were able to draw upon popular notions about language learning to legitimize their teaching practices in interviews with a language specialist, while drawing on contradictory ideologies to manage their classrooms. Such contradictions are not likely the product of willful deception by teachers rather they speak to how ideologies are jointly reproduced and sensitive to the imagined histories of co-present interlocutors. As Kroskrity (2004, p.503) remarks "viewing language ideologies as "normally" (or unmarkedly) multiple within a population focuses attention on their potential conflict and contention in social space" and provides a rich picture of the underlying tensions in the classroom or during interactions while studying abroad.

\section{Partiality}

The third fundamental aspect is the partiality of language ideologies. Many scholars maintain that language ideologies necessarily serve the interest of a specific social or cultural group and are therefore one of the many ways in which hegemonic relationships are perpetuated (Kroskrity, 2004). ${ }^{6}$ For the purposes of this paper, hegemony can be understood as the implicit or unarticulated

\footnotetext{
${ }^{6}$ As mentioned previously, not all work connects ideology explicitly with power, Silverstein’s (1992) work being a
} 
experiences of subordination or domination felt by non-dominant groups (see Philips, 1998 for a review). To again cite an example involving an English-only policy, Mori (2014) demonstrates how a teacher and one of her students in an adult ESL classroom drew on the English only policy in selfinterested ways to accomplish their own goals. She reported that the teacher tended to use it as a tool to keep students on task by eliminating off-topic gossip. In contrast, the student, a Farsi speaker, invoked the rule to prevent the Spanish-speaking majority from marginalizing her from Spanish gossip sessions. In this case, these ideologies (in the form of classroom rules) were mobilized locally to fulfill the immediate and divergent interests of the teacher and the Farsispeaking student.

In other cases, both students and teachers are complicit in reproducing language ideologies which place learners at the margins of society. For example, in Miller's (2009) work with adult immigrants in ESL classrooms, she details how in interviews she and her participants jointly recreate the ideological connection between US identity and English abilities, naturalizing the students' need to learn English as common sense and reinforcing their illegitimacy as US citizens. She demonstrates how such ideologies serve the interests of the English speaking majority by allowing them to maintain their privileged access to jobs and education. Scholars such as Miller, who focus on the power dimensions of language ideologies, call on researchers to critically examine whose interests are best served when language ideologies are naturalized, and to consider the consequences to others. Researchers adopting this perspective see language ideologies as "dominant ways of thinking that organize and stabilize societies while simultaneously determining modes of inclusion and exclusion, and the privileging and marginalization of ideas, people, and relations" (Darvin \& Norton, 2015, p.43). ${ }^{7}$

\section{Applying insights from language ideologies in SA}

Given these theoretical premises, a language ideology approach would complement pyschosocial beliefs research in several ways. Firstly, because language ideologies are viewed as coconstructed, research from this perspective adopts a more holistic approach and takes into account more stakeholders when explaining findings. This includes not only the parties with whom students interact, but the broader media and institutional messages that frame SA in particular ways. For instance, this might include the recruitment literature displaying exotic pictures of happy students, university policies concerning internationalization, and local discourses about second language proficiency for job hunting. Secondly, because language ideologies are viewed as inherently multiple and contradictory, cases in which students espouse one belief and subsequently behave in ways that violate that belief would not be viewed as lazy or hypocritical. A typical SA example of this might be students who continually assert beliefs about the importance of interacting with locals while only interacting with co-nationals during their sojourns. A language ideology approach would address the issue of how that belief functions differently as a meaning making resource in specific situated

good example. However, evidence of asymmetrical social relationships is almost always visible in language ideology research.

${ }^{7}$ In addition to the heterogeneity in definition, we also find a wide range of terminology. Silverstein preferred the term linguistic ideologies and conceived of them as "sets of beliefs about language articulated by users as a rationalization or justification of perceived language structure and use" (Silverstein, 1979, p.193). Others, such as Verschueren (2012) deliberately emphasize the indefinite form, language ideology, to emphasize the fluid and overlapping nature of the construct. 
contexts rather than blaming the student for failing to interact with locals in accordance with their beliefs. To illustrate the possible contributions of this perspective, I have selected three strands of ideology research - language policy, theories of language, and education and socialization - and describe how each parallels concerns in the SA context.

\section{Language policy}

The first strand is related to language policy and investigates ideologies that connect language abilities with broader categories of nationality, citizenship, and identity (Liddicoat, 2007; LippiGreen, 1997, 2004; Mar-Molinero \& Stevenson, 2006; Ricento, 2000; Zajda, 2010). These studies often address issues of "standard" or "monolingual" ideologies, or what has been referred to as the Herderian ideology of one language, one nation (Ricento, 2006; Woolard \& Schieffelin, 1994). For instance, Lippi-Green's (1997) highly influential volume on standard English ideologies in the United States problematizes the notion that "good" and "correct" English are the purview of those with above average education, no accent, and who pay particular attention to their speech. Research such as Lippi-Green's points out how such ideologies marginalize speakers of non-official languages or restrict their ability to legitimately claim desired and valued local identities. Critical discourse analysis (Blommaert, 2005; van Dijk, 1995; Verschueren, 2012) is often the method of choice for such studies, which rely on a range of public, media, and institutional texts.

SA policy and document analyses have already begun similar work by investigating the ideologies of global citizenship (Chen \& Belgeonne, 2007; Doerr, 2013) or colonialism (Caton \& Santos, 2009). Thomas (2013) also recently critically evaluated discourses on the underrepresentation of racial minority students in the US SA literature. Among other issues, he points out that by categorizing bodies principally by ethnicity, scholars "ignore intragroup differences", "override any differences in social practices that might arise due to differing SES (socio-economic status)", and finally present lack of participation as "specifically a minority problem" (pp.370-371). Similar critically-oriented research on SA policy specifically about language may prove useful in illuminating the historical context that undergirds students' practices and beliefs about language learning in SA. De Costa (2010) and Park and Bae (2009), for instance, have investigated how different educational systems place value on different language varieties (e.g., Mandarin and English as a global language) and how this impacts the beliefs and choices expressed by high school SA students and their parents in Singapore.

\section{Theories of language}

The second strand addresses the issue of ideological biases in the study of language itself, investigating how understandings of language within academic disciplines have shaped the focus and methods of inquiry (e.g., Harissi, Otsuji, \& Pennycook, 2012; Jenkins, 2009; Seargeant, 2008). Blommaert (2006) provides an excellent overview of this perspective, problematizing notions of languages as countable and bounded systems, the stability of texts, and the homogeneity of speech communities. Native speaker ideologies have likewise been at the centre of a number of recent debates since the publication of several articles in the 1990s (e.g., Firth \& Wagner, 1997; Rampton, 1990) which challenged the use of native speaker language as the appropriate target for acquisition. These studies use the language ideologies construct to "dislodge a range of established concepts and categories and thus offer infinite opportunities for revisiting existing scholarship" (Blommaert, 2006, p.511). In short, by highlighting the ideological nature of assumptions in the field, these scholars 
open new theoretical spaces for alternative visions of language competence (May, 2014). This type of research is most closely related to folklinguistic theories which were investigated by Miller and Ginsberg (1995) in the SA context. The difference between research in folklinguistic theories and language ideology is that folklinguistics draws a clear line between popular or lay understandings of language and scholarly understandings of language (Wilton \& Stegu, 2011), while a language ideology framework views all notions of language learning as inherently ideological. The application of this framework would therefore examine how the SA students' and scholars' beliefs are permutations and transformations of similar socially circulating ideologies, allowing a clearer bidirectional link to be established rather than a hierarchical, one-way relationship.

Doerr (2015) recently addressed this type of ideology in the SA context by challenging the tendency of SA research and advertising to connect learning with linguistic immersion, noting how SA uncritically privileges experiential learning models. She observes through analysis of advertising that SA promises cultural and linguistic immersion in the host country but that "the notion of immersion itself is seldom critically investigated, as most discussions on immersion focus on supplementary activities to ensure its effectiveness" (p.371). She then describes the experiences of three American undergraduates in Europe, illustrating how while all three recognized that they "should" be attempting to immerse themselves through interaction with locals, two of them placed more value on learning from their fellow Americans or other international students. This type of research shows how ideologies about language learning, in this case the value of learning through experiential immersion, can simultaneously be recognized and resisted by students and points to possible news ways of thinking about what constitutes valuable types of learning in the SA context.

\section{Education and socialization}

The final strand of language ideology research focuses on educational contexts and more specifically on how circulating beliefs about language and language learning impact and are impacted by educational practices, activities and policies (Asker \& Martin-Jones, 2013; Carter, 2014; Katz, 2000; Miller, 2009; Mori, 2014; Needham, 2003; Palmer, 2011; Pomerantz, 2005; Razfar \& Rumenapp, 2012; Razfar, 2005, 2012). These studies draw on a wide range of data, including recordings and observations, interviews with students and teachers as well as institutional policy documents to provide a rich context for the ways in which these various ideologies are maintained and reproduced in classroom practice. Similar to qualitative beliefs work in SA, findings from these studies often demonstrate the contradictory nature of ideologies and the intersection between identity and language. However, instead of treating such contradictions as illogical, researchers seek to understand why such contradictions occur and who benefits when particular ideologies are invoked.

For example, in her investigation of language ideologies in English courses at a factory in Silicon Valley with a predominantly Mexican workforce, Katz (2000) compared official company documents, which marketed English as a neutral tool or skill of the workplace, to circulating discourses about the classes as observed on the worksite. Findings revealed that rather than providing language tools, lessons addressed what management perceived as culturally inappropriate language use at work, namely a refusal to provide spontaneous feedback and recommendations. This mismatch between the stated aims and hidden curriculum contributed to tension between 
management and workers, with many workers expressing explicit resistance to the notion of speaking up despite being aware that not doing so limited their possibilities for promotion.

Unlike most qualitative SA research which investigates sojourners' perspectives, Katz's study explicitly accounts for the viewpoints of multiple stakeholders including workers, management and herself as an assistant instructor. It also highlights how simply telling the workers to change their assumptions and practices was ineffectual. Workers were already aware of the norm connecting "speaking out" and job advancement but felt that it was more important to prioritize other competing ideologies of silence that allowed them to maintain face with co-workers. For SA, this implies that even if instructors make students aware of unrealistic expectations, students may resist changing them in meaningful ways for all manner of reasons. Insights from this strand of research could profitably be applied to investigating naturalistic interaction in homestays, language classes, and tandem language exchanges during a sojourn (e.g., Cook, 2006; Diao, 2014; Dings, 2012; Iino, 2006).

\section{Conclusion}

SA has long enjoyed the unquestioning support of the general public and governments and its benefits for language learning in many ways have been naturalized as "common sense" (Twombly et al., 2012). Language ideology scholars would say that this naturalization itself is indication that there are strong ideological forces at work (Kroskrity, 2004; Verschueren, 2012). I advance that, given the political push to increase the number of sojourning students, we must continue to critically investigate what ideological load might be permeating the SA context. In my view, by conceptualizing students' attitudes and beliefs toward language as ideological we can move past the actions of individuals to look at the broader processes "shared across individuals and implicated in power relations" (Pomerantz, 2006, p.280). While it is individuals who use language ideologies as resources, individuals are never viewed as their sole proprietors or creators. For SA, this implies that students' attitudes about learning languages abroad have broader historical antecedents constructed through interactions with friends, faculty, family, media, and institutional policy. By adopting the understanding that language ideologies are necessarily partial, researchers are also forced to ask who benefits when SA is framed in this way: the students themselves, institutions, or perhaps a particular type of language learner? As I have noted throughout this paper, a number of SA researchers have begun this process by adopting critical approaches and pointing to the broader societal discourses that shape students' experiences. A language ideological framework provides an additional theoretical tool for connecting everyday practices to broader societal discourses. Further work could examine the ways in which recruitment documents and institutional policies shape students' expectations of their SA experience or investigate how students use circulating language ideologies to rationalize their actions or reactions during their sojourns.

\section{Acknowledgements}

I would like to thank the reviewers for their insightful comments on previous versions of this manuscript as well as Dr. Patricia Duff, Dr. Steven Talmy, and Dr. Sandra Zappa-Hollman for their valuable input. This paper was completed with funding provided by the Social Sciences and Humanities Research Council of Canada. 


\section{References}

Allen, H. W. (2010). Language-learning motivation during short-term study abroad: An activity theory perspective. Foreign Language Annals, 43(1), 27-49. doi:10.1111/j.1944-9720.2010.01058.x

Allen, H. W., \& Dupuy, B. (2012). Study abroad, foreign language use, and the communities standard. Foreign Language Annals, 45(4), 468-493. doi:10.1111/j.1944-9720.2013.01209.x

American Council on Education. (2008). College-bound students' interests in study abroad and other international learning activities. Retrieved from https://www.acenet.edu/newsroom/Documents/2008-Student-Poll.pdf

Amuzie, G. L., \& Winke, P. (2009). Changes in language learning beliefs as a result of study abroad. System, 37(3), 366-379. doi:10.1016/j.system.2009.02.011

Asker, A., \& Martin-Jones, M. (2013). "A classroom is not a classroom if students are talking to me in Berber": Language ideologies and multilingual resources in secondary school English classes in Libya. Language and Education, 27(4), 343-355. doi:10.1080/09500782.2013.788189

Benson, P., Barkhuizen, G., Bodycott, P., \& Brown, J. (2012). Study abroad and the development of second language identities. Applied Linguistics Review, 3(1), 173-193. doi:10.1515/applirev-20120008

Blommaert, J. (2005). Discourse. New York: Cambridge University Press.

Blommaert, J. (2006). Language ideology. In K. Brown, (Ed.), Encylopedia of language and linguistics (Vol. 6, pp. 510-522). Oxford, UK: Elsevier.

Brux, J. M., \& Fry, B. (2010). Multicultural students in study abroad: Their interests, their issues, and their constraints. Journal of Studies in International Education, 14(5), 508-527.

Carter, P. (2014). National narratives, institutional ideologies, and local talk: The discursive production of Spanish in a "new" US Latino community. Language in Society, 43(2), 209-240.

Caton, K., \& Santos, C. a. (2009). Images of the Other: Selling study abroad in a postcolonial world. Journal of Travel Research, 48(2), 191-204. doi:10.1177/0047287509332309

Chen, L., \& Belgeonne, C. (2007). Global citizenship \& study abroad: It's all about U.S. Critical Literacy: Theories and Practices, 1(2), 16-28.

Cook, H. M. (2006). Joint construction of folk beliefs by JFL learners and Japanese host families. In M. A. DuFon \& E. Churchill (Eds.), Language learners in study abroad contexts (pp. 120-150). Clevedon: Multilingual Matters.

Darvin, R., \& Norton, B. (2015). Identity and a model of investment in applied linguistics. Annual Review of Applied Linguistics, 35, 36-56. doi:10.1080/14759550903558201

De Costa, P. (2010). Language ideologies and standard English language policy in Singapore: Responses of a "designer immigrant" student. Language Policy, 9(3), 217-239. doi:10.1007/s10993-010-9176-1

De Costa, P. (2011). Using language ideology and positioning to broaden the SLA learner beliefs landscape: The case of an ESL learner from China. System, 39(3), 347-358. doi:10.1016/j.system.2011.07.007

DeKeyser, R. (2010). Monitoring processes in Spanish as a second language during a study abroad program. Foreign Language Annals, 43(1), 80-92. doi:10.1111/j.1944-9720.2010.01061.x

Diao, W. (2014). Peer socialization into gendered L2 Mandarin practices in a study abroad context: Talk in the dorm. Applied Linguistics, 1-23. doi:10.1093/applin/amu053

Diao, W., Freed, B., \& Smith, L. (2011). Confirmed beliefs or false assumptions? A study of home stay experiences in the French study abroad context. Frontiers: The Interdisciplinary Journal of Study Abroad, 21, 109-143.

Dings, A. (2012). Native speaker/nonnative speaker interaction and orientation to novice/expert identity. Journal of Pragmatics, 44(11), 1503-1518. doi:10.1016/j.pragma.2012.06.015 
Doerr, N. M. (2012). Study abroad as "adventure": Globalist construction of host-home hierarchy and governed adventurer subjects. Critical Discourse Studies, 9(3), 257-268. doi:10.1080/17405904.2012.688211

Doerr, N. M. (2013). Do "global citizens" need the parochial cultural other? Discourse of immersion in study abroad and learning-by-doing. Compare: A Journal of Comparative and International Education, 43(2), 224-243. doi:10.1080/03057925.2012.701852

Doerr, N. M. (2015). Learner subjects in study abroad: discourse of immersion, hierarchy of experience and their subversion through situated learning. Discourse: Studies in the Cultural Politics of Education, 36(3), 369-382. doi:10.1080/01596306.2013.871448

Firth, A., \& Wagner, J. (1997). On discourse, communication, and (some) fundamental concepts in SLA research. The Modern Language Journal, 81(3), 285-300.

Freed, B. (1998) An overview of issues and research in language learning in a study abroad setting. Frontiers: The Interdisciplinary Journal of Study Abroad, 4, 31-60.

Gal, S. (1998). Multiplicity and contention among ideologies. In B. Schieffelin, K. Woolard, \& P. Kroskrity (Eds.), Language ideologies: Practice and theory (pp. 318-331). New York: Oxford University Press.

Gilmore, A. (2007). Authentic materials and authenticity in foreign language learning. Language Teaching, 40(02), 97. doi:10.1017/S0261444807004144

Gore, J. E. (2005). Dominant Beliefs and Alternative Voices. Discourse, Belief, and Gender in American Study Abroad. New York: Routledge.

Harissi, M., Otsuji, E., \& Pennycook, A. (2012). The performative fixing and unfixing of subjectivities. Applied Linguistics, 33, 524-543. doi:10.1093/applin/ams053

Härkönen, A., \& Dervin, F. (2015). Study abroad beyond the usual "imagineering"? The benefits of a pedagogy of imaginaries. East Asia, 33(1), 41-58. doi:10.1007/s12140-015-9247-1

Hernández, T. A. (2010). The relationship among motivation, interaction, and the development of second language oral proficiency in a study-abroad context. The Modern Language Journal, 94(4), $600-617$.

Iino, M. (2006). Norms of interaction in a Japanese homestay setting: Toward a two-way flow of linguistic and cultural resources. In M. A. DuFon \& E. Churchill (Eds.), Language learners in study abroad contexts (pp. 151-202). Clevedon: Multilingual Matters.

Isabelli-Garcia, C. (2004). A case study of the factors in the development of Spanish linguistic accuracy and oral communication skills: Motivation and extended interaction in the study abroad context. New York: Edwin Mellen Press.

Izumi, S., Shiwaku, R., \& Okuda, T. (2011). Beliefs about language learning, learning strategy use, and self-efficacy/confidence of EFL learners with and without living-abroad experience. Sophia Linguistica, 59, 151-184. Retrieved from http:/ / cat.inist.fr $/$ ?aModele $=$ afficheN\&cpsidt $=25884792$

Jackson, J. (2008). Language, identity, and study abroad: Sociocultural perspectives. London: Equinox.

Jenkins, J. (2009). English as a lingua franca: Interpretations and attitudes. World Englishes, 28(2), 200207. doi:10.1111/j.1467-971X.2009.01582.x

Katz, M. (2000). Workplace langauge teaching and the intercultural construction of ideologies of competence. The Canadian Modern Language Review, 57(1), 144-172.

Kaypak, E., \& Ortaçtepe, D. (2014). Language learner beliefs and study abroad: A study on English as a lingua franca (ELF). System, 42, 355-367.

Kinginger, C. (2008). Language learning in study abroad: Case studies of Americans in France. The Modern Language Journal, 92, 1-124. doi:10.1111/j.1540-4781.2008.00821.x

Kinginger, C. (2009). Language learning and study abroad. London: Palgrave Macmillan. 
Kroskrity, P. (2004). Language ideologies. In A. Duranti (Ed.), A Companion to linguistic anthropology (pp. 496-517). Malden, MA: Blackwell.

Lee, J. (2014). Experiences of intensive English learners: Motivations, imagined communities, and identities. English Language Teaching, 7(11), 28-38. doi:10.5539/elt.v7n11p28

Li, M., Olson, J. E., \& Hanson Frieze, I. (2012). Students' study abroad plans: The influence of motivational and personality factors. Frontiers: The Interdisciplinary Journal of Study Abroad, 24, 7389.

Liddicoat, A. J. (2007). The ideology of interculturality in Japanese language-in-education policy. Australian Review of Applied Linguistics, 30(2), 20.1-20.16. doi:10.2104/aral.v30i2.1956

Lippi-Green, R. (1997). English with an accent: Language, ideology, and discrimination in the United States. New York: Routledge.

Lippi-Green, R. (2004). Language ideology and language prejudice. In E. Finegan \& J. Rickford (Eds.), Language in the USA: Themes for the twenty-first century (pp. 289-304). New York: Cambridge University Press.

Mar-Molinero, C., \& Stevenson, P. (Eds.). (2006). Language ideologies, policies and practices: Language and the future of Europe. Basingstoke, Hampshire: Palgrave Macmillan.

May, S. (2014). Disciplinary divides, knowledge construction and the multilingual turn. In S. May (Ed.), The multilingual turn: Implications for SLA, TESOL, and bilingual education (pp. 7-31). New York: Routledge.

Mendelson, V. G. (2002). "Hindsight is 20/20": Student perceptions of language learning and the study abroad experience. Frontiers: The Interdisciplinary Journal of Study Abroad, 10, 43-63.

Miller, E. (2009). Orienting to "being ordinary": the (re)construction of hegemonic ideologies in interactions among adult immigrant learners of English. Critical Inquiry in Language Studies, 6(4), 315-344. doi:10.1080/15427580903337446

Miller, L. \& Ginsberg, R. (1995) Folklinguistic theories of language learning. In B. Freed (Ed.), Second language acquisition in a study abroad context (pp. 293-315). Amsterdam: John Benjamins.

Mori, M. (2014). Conflicting ideologies and language policy in adult ESL: Complexities of language socialization in a majority-L1 classroom. Journal of Language, Identity \& Education, 13(3), 153-170. doi:10.1080/15348458.2014.919810

National Standards in Foreign Language Education Project, (2006). Standards for foreign language learning in the $21^{\text {st }}$ century. $3^{\text {rd }}$ ed. Alexandria, VA: Author.

Needham, S. (2003). "This is active learning": Theories of language, learning, and social relations in the transmission of Khmer literacy. Anthropology \& Education Quarterly, 34, 27-49.

Nguyen, S. (2014). " $F$ " is for family, friend and faculty influences: Examining the communicated messages about study abroad at a Hispanic-serving institution (HSI). International Education, 43(2), 77-94.

Olivo, W. (2003). “Quit talking and learn English!”: Conflicting language ideologies in an ESL classroom. Anthropology \& Education Quarterly, 34(1), 50-71. doi:10.1525/aeq.2003.34.1.50

Palmer, D. (2011). The discourse of transition: Teachers' language ideologies within transitional bilingual education programs. International Multilingual Research Journal, 5(2), 103-122. doi:10.1080/19313152.2011.594019

Park, G. (2012). "I am never afraid of being recognized as an NNES": One teacher's journey in claiming and embracing her nonnative-speaker identity. TESOL Quarterly, 46(1), 127-151. doi:10.1002/tesq.4

Park, J., \& Bae, S. (2009). Language ideologies in educational migration: Korean jogi yuhak families in Singapore. Linguistics and Education, 20, 366-377.

Pellegrino, V. (1998). Student perspectives on language learning in a study abroad context. Frontiers: The Interdisciplinary Journal of Study Abroad, 4, 91-120. 
Pellegrino, V. (2005). Study abroad and second language use: Constructing the self. New York: Cambridge University Press.

Philips, S. (1998). Language ideologies in institutions of power. In B. Schieffelin, K. Woolard, \& P. Kroskrity (Eds.), Language ideologies: Practice and theory (pp. 211-225). New York: Oxford University Press.

Pomerantz, A. (2005). Conversation analytic approach to the relevance and uses of relationship categories in interaction. In K. L. Fitch \& R. E. Sanders (Eds.), Handbook of language and social interaction (pp. 149-171). Mahwah, NJ: Lawrence Erlbaum Associates.

Pomerantz, A. (2006). Language ideologies and the production of identities: Spanish as a resource for participation in a multilingual marketplace. Multilingua - Journal of Cross-Cultural and Interlanguage Communication, 21(2002), 275-302. doi:10.1515/mult.2002.012

Pyper, M. J., \& Slagter, C. (2015). Competing priorities: Student perceptions of helps and hindrances to language acquisition during study abroad. Frontiers: The Interdisciplinary Journal of Study Abroad, 26(224), 83-106.

Rampton, M. B. H. (1990). Displacing the "native speaker": Expertise, affiliation, and inheritance. ELT Journal, 44(2), 97-101. doi:10.1093/elt/44.2.97

Razfar, A. (2005). Language ideologies in practice: Repair and classroom discourse. Linguistics and Education, 16(4), 404-424. doi:10.1016/j.linged.2006.04.001

Razfar, A. (2012). Narrating beliefs: A language ideologies approach to teacher beliefs. Anthropology and Education Quarterly, 43(1), 61-81. doi:10.1111/j.1548-1492.2011.01157.x

Razfar, A., \& Rumenapp, J. C. (2012). Language ideologies in English learner classrooms: Critical reflections and the role of explicit awareness. Language Awareness, 21(4), 347-368. doi:10.1080/09658416.2011.616591

Ricento, T. (2000). Ideology, politics and language policies: Focus on English. Amsterdam: John Benjamins.

Ricento, T. (2006). Americanization, language ideologies and the construction of European identities. In C. Mar-Molinero \& P. Stevenson (Eds.), Language ideologies, policies and practices (pp. 44-57). Basingstoke, Hampshire: Palgrave Macmillan.

Rumsey, A. (1990). Wording, meaning, and linguistic ideology. American Anthropologist, 92(2), 346361.

Schieffelin, B., Woolard, K., \& Kroskity, P. (Eds.) (1998). Language ideologies: Practice and theory. New York: Oxford University Press.

Seargeant, P. (2008). Language, ideology and "English within a globalized context." World Englishes, 27(2), 217-232. doi:10.1111/j.1467-971X.2008.00553.x

Siegal, M. (1996). The role of learner subjectivity in second language sociolinguistic competency: Western women learning Japanese. Applied Linguistics, 17(3), 356-382.

Silverstein, M. (1979). Language structure and linguistic ideology. In P. Clyne, W. Hanks, \& C. Hofbauer (Eds.), The elements: A parasession on linguistic units and levels (pp. 193-247). Chicago: Chicago Linguistic Society.

Silverstein, M. (1992). The uses and utility of ideology: Some reflections. Pragmatics, 2(3), 311-323.

Sivakumaran, T., Tomida, E., Hall, H. K., \& Sumida, M. (2013). Exploring factors determining motivation to participate in study abroad programs for teacher education students in the U.S.A. and Japan. International Journal of Business and Social Science, 4(6), 1-9.

Stroud, A. H. (2010). Who plans (not) to study abroad? An examination of U.S. student intent. Journal of Studies in International Education, 14(5), 491-507.

Tanaka, K., \& Ellis, R. (2003). Study-abroad, language proficiency, and learner beliefs about language learning. JALT Journal, 25(1), 63-85.

Thomas, M. (2013). The problematization of racial/ethnic minority student participation in U.S. study abroad. Applied Linguistics Review, 4(2), 365-390. doi:10.1515/applirev-2013-0016 
Trenchs-Parera, M., \& Juan-Garau, M. (2014). Learner's motivations and beliefs at home and abroad. In C. Pérez-Vida (Ed.), Language Acquisition in Study Abroad and Formal Instruction Contexts (p. 329). Amsterdam: John Benjamins.

Trentman, E. (2013). Imagined communities and language learning during study abroad: Arabic learners in Egypt. Foreign Language Annals, 46(4), 545-564.

Twombly, S., Salisbury, M., Tumanut, S., \& Klute, P. (2012). Study abroad in a new global century: Renewing the promise, refining the purpose. San Francisco: Wiley.

van Dijk, T. (1995). Discourse semantics and ideology. Discourse \& Society, 6(2), 243-289. doi:0803973233

Verschueren, J. (2012). Ideology in language use: Pragmatic guidelines for empirical research. New York: Cambridge University Press.

Wanger, S. P., Minthorn, R. S., Appleman, B., James, M., \& Arnold, A. (2012). Participation in study abroad: An exploratory case study. American Indian Culture and Research Journal, 36(4), 127-152.

Wilkinson, S. (1998). On the nature of immersion during study abroad: Some participant perspectives. Frontiers: The Interdisciplinary Journal of Study Abroad, 4, 121-138.

Wilton, A., \& Stegu, M. (2011). Bringing the "folk" into applied linguistics: An introduction. AIL $A$ Review, 24(1), 1-14. doi:10.1075/aila.24.01wil

Woolard, K. (1998). Introduction: Language ideology as a field of inquiry. In B. Schieffelin, K. Woolard, \& P. Kroskrity (Eds.), Language ideologies: Practice and theory (pp. 3-47). New York: Oxford University Press.

Woolard, K., \& Schieffelin, B. (1994). Language ideology. Annual Review of Anthropology, 23(1), 55-82. doi:10.1146/annurev.an.23.100194.000415

Yang, J.-S., \& Kim, T.-Y. (2011). Sociocultural analysis of second language learner beliefs: A qualitative case study of two study-abroad ESL learners. System, 39(3), 325-334. doi:10.1016/j.system.2011.07.005

Yen, W., \& Stevens, P. (2004). Taiwanese students' perspectives on their educational experiences in the United States. Journal of International Education, 5(3), 294-307.

Zajda, J. (Ed.). (2010). Globalisation, ideology and education policy reforms. New York: Springer.

Zemach-Bersin, T. (2009). Selling the world. In R. Lewin (Ed.), The Handbook of practice and research in study abroad (pp. 303-320). New York: Routledge.

Zhang, Y. L., \& Sun, J. (2014). Studying overseas: Factors impacting intention of female students in Mainland China. Journal of International Students, 3(2), 140-154. 